\title{
China
}

\section{Development of criminal law in China since the introduction to the reform and opening-up policy}

\author{
by Ye Feng
}

$\mathrm{D}$ evelopment of the criminal law system in the People's Republic of China has undergone a long and tortuous process. The preparation and drafting of the First Penal Code, the 1979 Penal Code, began in 1954. The draft was revised 38 times over 25 long years and was not adopted until the Second Session of the Fifth National People's Congress. Due to the limitations inherent in the political, economic, cultural and social order conditions prevailing at the time, as well as to the relative lack of experience in legislation, the Penal Code was so conservative in concept and the contents so vague that the inconsistencies with the social realities became apparent within a very short time. In particular, this was because China also launched its reform and opening-up policy at the same time as the 1979 Penal Code was adopted. With the continuing development of the market economy (first known in China as the 'commodity market') and China's ever-increasing international contacts, as well as the enormous changes in all areas of social life, all kinds of economic and other crimes endangering social order began to occur and increase in seriousness as never before. The 1979 Penal Code became increasingly incapable of dealing with such crimes.

In order to properly address the new situation and new problems stemming from the country's reform and opening-up policy, as well as to meet the practical needs of punishment and prevention of crime, China's supreme legislative body adopted 25 separate criminal laws between 1981 and 1995, attached criminal clauses (or criteria defining criminal acts) in over 90 laws concerning economic, civil, administrative, educational, environmental pollution and social security matters, and made a large number of revisions and additions to the 1979 Penal Code. These moves certainly helped to meet the urgent needs arising from the social situation and played a marked and powerful role in guiding and standardising the practice of criminal justice in China. However, due to the existence of so many separate criminal law documents and criteria for criminal behaviour outside the Penal Code, there was an inevitable lack of a systematic definition of crime. At the some time there was no integrated entity, causing difficulties in the handling of cases. Although certain regulations in the code were improved on an interim basis, the unsuitable parts of separate laws and regulations and inconsistencies between or among them again became apparent. Both the theory and practice of the administration of justice showed the need for a comprehensive revision of criminal law and the formulation of an entirely new penal code in order to effectively improve Chinese criminal law.

It took 15 years for China to study and revise the Penal Code. This process can be roughly divided into five stages:

(1) Preparation (January 1982 - February 1988) - the highest legislative body began collecting and making a summary of opinions about revising criminal law.
(2) The beginning of revision (March 1988 - June 1989) - criminal law revision was listed in the legislation plan and a Revised Draft Criminal Law was formulated.

(3) Revision of key areas (1991) - necessity of changing the term 'counter-revolutionary crimes' into 'crimes endangering state security' was discussed and confirmed.

(4) Comprehensive, systematic revision (January 1993 December 1996) - the highest legislative body stepped up revision work, formulating many draft laws.

(5) Deliberation and adoption (December 1996 - March 1997) - the highest legislative body solicited opinions from all sectors of society, held numerous rounds of deliberation on the revised draft and finally adopted the new Criminal Law of the People's Republic of China ('New Penal Code') on 14 March 1997 at the Fifth Session of the Eighth National People's Congress (NPC, Parliament). The New. Penal Code came into effect on 1 October 1997

The New Penal Code is divided into three sections: General Provisions, Specific Provisions and Supplementary Provisions, consisting of 15 chapters, 37 sections, 452 articles and 58,159 Chinese characters. The number of articles was increased from 192 to 452 and the number of criminal charges from 152 to 413. The scope and breadth of this revision was unprecedented in China. The code meets the needs of the time and gives a strong impetus to the rule of law in China in terms of the prosecution of criminal offences as well as the process of developing laws in general, and thus represents a milestone in the history of new China's legal system.

\section{BACKGROUND}

The basic rationale behind the revision of the criminal law is to reflect the real situation in our country and listen attentively to the views of the masses. The theoretical basis guiding the revision of the criminal law is as follows:

(1) The new criminal law must be strong enough to combat various kinds of crimes. Since 1979, the economy of our country has developed very quickly. It brings us wealth, but also many side effects, including an increase in serious crime. Moreover, new kinds of crimes are occurring. These problems seriously disrupt the normal society order.

(2) The new criminal law must aim to protect the legal benefits of the whole country, the society, and the citizen. We must not only attack crimes but also protect legal rights. If we punish the crimes committed by the minority, we will protect the legal rights of the majority. The legal rights of the citizen must be protected from violation by judicial officials or the administrative law executive. 
(3) The new criminal law must assist the establishment and development of the socialist market economy. During the changeover from planned economy to market economy, the crimes that existed before adopted many new characteristics, and many new kinds of crime appeared. Therefore, when we revise the criminal law we must not only include established definitions, but also predict possible future crimes.

(4) The new criminal law must help strengthen the management of society. As a basic law, the criminal law exercises control over every aspects of society. With the emergence of many new social problems, the revised criminal law must control society more effectively

\section{Four main principles}

When we revise the criminal law, we follow four main principles:

(1) The crime and its punishment must be clearly stipulated in the criminal law. This principle must be embodied in both the general and special provisions of the new criminal law.

(2) Everyone is equal before the law. One of the major problems of the 1979 criminal law is that, although one crime may be similar to another in character and method, the punishments stipulated in the criminal law are very different.

(3) The new criminal law must insist on the principle of seeking truth from the facts. The revised criminal law must not only fight crime but also reflect the special nature of Chinese society.

(4) The revised criminal law should try to stipulate details of every provision, reflecting the experience gained since 1979 in revising the criminal law, promulgating many new supplements and making great improvements in research into the theory of criminal lav.

\section{PARTICIPANTS IN THE PROCESS}

Many institutions and individuals participated in the various stages of the process of the revision of the criminal law, such as the law school of the People's University, the law school of Beijing University, the Institution of Social Science, the Institution of Procuratorial Theory and eminent jurists, such as the well-known criminologists GAO Mingxuan and ZHAO Bingzhi.

Professor GAO was involved in formulating the 1979 criminal law. This time he and his assistants, along with other professors, put forward a first draft of the general provisions of the criminal law. The law committee of the NPC was in charge of revising the specific provisions of the criminal law. Initially, the law committee added these two sets of provisions together and distributed the draft to the court, the procuratorate, the public security organ and law bureau of the state council to ask for criticism. Legal institutions and jurists also put forward their own opinions to the law committee. These opinions were synthesised and added to the revised criminal law. The law committee then appointed ten jurists to study each provision of the revised manuscript, following which the draft was returned to the court, the procuratorate, the public security organ, institutions and individuals to seek their opinions one more time. Eventually, on 14 March 1997, the Eighth Session of the National People's Congress passed the draft of the revised criminal law, which was carried out formally on 1 October 1997.

Of course there were conflicting opinions on the revision of the criminal law, as every department, institution and individual has a different interest and background. That is understandable. When there was any controversy, the NPC balanced the different interests and made the final decision.

\section{MORE UNIFORM AND COMPREHENSIVE}

One of the most important objectives of the current revision of criminal law and the promulgation of the new penal code was to make criminal law more uniform and comprehensive. This objective was achieved in a number of ways.

First, through a process of deliberation and revision, all the regulations and decisions relating to criminal law (or separate criminal laws) adopted by the NPC Standing Committee in the 17 years since the 1979 Penal Code came into effect were combined to make the new penal code. To specific clauses of civil, economic and administrative laws and regulations defining criminal behaviour (or attached criteria for criminal behaviour) was added the phrase 'in pursuance of' or 'in reference to' the 1979 Penal Code. The 25 separate criminal laws adopted by the NPC Standing Committee from 1981 to 1995 covered a very wide range of crimes and consisted mostly of provisions defining criminal responsibility for economic crimes, as well as the punishment for such crimes as smuggling, endangerment of tax collection, fake trademark registration, production and marketing of shoddy goods, copyright infringement, harming the orderly management of business or enterprise and disruption of financial stability.

Between the promulgation of the 1979 Penal Code and the adoption of the new 1997 Penal Code, the number of laws with attached criminal law clauses grew to over 90. According to statistics from the highest legislative body, there were over 130 criminal law provisions attached to civil, economic, administrative and other non-criminal laws stipulating criminal charges 'in pursuance of' or 'in reference to' the criminal law. For example, there were criteria for criminal behaviour in the Marine Environmental Protection Law, the Trademark Law, the Cultural Relics Protection Law, the Food Hygiene Law and the Statistics Law. These separate criminal laws, together with criteria for criminal behaviour in other laws, laid the foundation for the creation of the new penal code and most were incorporated. Of course, certain criminal charges no longer compatible with current social needs were eliminated in the new code; for instance, the crime of counterfeiting and using ration coupons for speculative purposes specified in art. 120 of the 1979 Penal Code was not retained since the reason for its existence, i.e. the use of ration coupons, no longer exists.

Secondly, the existing Draft Anti-Corruption Law and the Draft Laws and Regulations on the Punishment of Servicemen for Dereliction of Duty, submitted by the Central Military Commission to the NPC Standing Committee for deliberation, were incorporated into the new penal code. Chapter 8 in the Specific Provisions of the new code contains provisions concerning crimes of corruption, embezzlement and bribery and Chapter 10 contains provisions concerning crimes of servicemen's transgression of duties. 
The regulations in the 1979 Penal Code on bribery and other forms of corruption were too simple. Only four types of crime were defined: corruption, bribe-taking, bribery and brokerage bribery, with the first grouped under property encroachment and the other three under malfeasance or dereliction of duty. The 1988 Supplementary Regulations on Punishment for Bribery and Other Corruption Crimes, promulgated by the NPC Standing Committee, had made major revisions and additions to the relevant regulations in the 1979 Penal Code and represented the first step in efforts to establish a fairly comprehensive system for defining bribery and other acts of corruption, including bribetaking, bribery, embezzlement of public funds, unclear origin of huge assets and concealment of deposits abroad.

To meet the need to combat corruption and strengthen efforts to crack down on bribery and other forms of corruption, the highest legislative body originally planned to formulate a special normative anti-corruption and bribery document (the Anti-Corruption and Bribery Law) to be drafted by the Supreme People's Procuratorate. Proceeding from the principle of devising a unified, relatively complete, penal code, the current revision embraced the compilation of the Additional Regulations on Punishing Corruption and Bribery Crimes (adopted by the NPC Standing Committee in 1988) and the anti-corruption and bribery law (now being drafted by the Supreme People's Procuratorate) in a chapter in the specific provisions of the new penal code. New charges, such as illegal distribution of stateowned assets and illegal distribution of fines and confiscation were added and the anti-corruption and bribery criminal punishment norms made more effective and descriptive. The legislative body has incorporated the Draft Regulations of the People's Republic of China on the Punishment of Servicemen for Anti-Duty Crimes, which was submitted by the Central Military Commission to the Standing Committee of the Eighth NPC for deliberations, into the new penal code as the final chapter of the Specific Principles, after making certain revisions and additions. Such a measure has guaranteed the completeness of the new penal code system as well as the authenticity of its role and functions; it is also conducive to putting the army onto the modern rule-of-law track.

Thirdly, in compliance with the practical need for the criminal law to protect the healthy development of the market economy and to safeguard state and social stability under the social market economy, the new penal code has greatly strengthened the categories of charges. From the point of view of the crime categories in the chapters and articles covered, the new Specific Principles section has created a special chapter on crimes endangering national defence, besides adding a new chapter incorporating servicemen's offences and creating a separate chapter dealing with corruption and bribery. At the same time, it has substantiated and divided into eight sections the third chapter, which dealt with crimes disrupting the socialist market economy; and substantiated and divided into nine sections the sixth chapter, which dealt with crimes impeding social administration. The new penal code has added over 150 new charges besides retaining most of those in the 1979 Penal Code as well as others added later, bringing the number of offences in China's criminal law to a total of 413. Such crimes as organising, leading or joining terrorist organisations, hijacking ships or vehicles, are all new charges. The addition of new offences, relating to new categories of crime, has strengthened and modernised China's new penal code, which will help to bring about social development and prosperity.

Part Two of this article will be published in the next issue of Amicus Curiae. (1)

\section{Dr Ye Feng}

Senior member of the Supreme People's Procuratorate; Director of the Institute of Procuratorial Theory; Secretary General of the Society of Public Prosecutors of China

\section{The Netherlands}

\section{Contingency fees entering the Dutch legal system by Leny E de Groot-van Leeuwen}

I $\mathrm{n}$ the Netherlands the wind blows from the west most of the time. Perhaps that is why the Dutch adopt so many legal features and procedures from the US, such as plea bargaining, alternative dispute resolution and contingency fees for attorneys. The discussion on contingency fees (or 'no cure, no pay' as the Dutch say) flared up recently, sparked by Attorney Mr G Engelgeer, who sued the Dutch Bar Association (Nederlandse Orde van Advocaten ('NOVA') for not allowing them.

According to this attorney, the restrictions the DBA imposes on competition among its members violate the national and European law. Mr Engelgeer grounds his complaints in a recently published set of 'points for consideration' from the Dutch Competition Authority (Nederlandse mededigingsautoriteit, 'NMa') in which it is stated that the current prohibition on contingency fees should be banned.

The complaints against the NOVA have fallen on fertile soil This soil has been prepared by the European Union, which views the Netherlands as a paradise for cartels. The EU has forced the NMa to adopt a strictly pro-competition stance, with the objective of pushing the Dutch style of conducting business in a more open-market direction (without sacrificing the Dutch culture of consensus, i.e. the much-praised 'polder model', to which the cartel-style of business is closely connected).

The NMa's view is only one stone in an avalanche of decisions pertaining to all other sectors of business. The relevance of the contingency fees case lies at a deeper level, in that, as far as the 